\title{
Effectiveness of Contextual Teaching and Learning (CTL) to Improve Students Achievement and Students' Self-Efficacy in Cognitive Psychology Course
}

\author{
Hazhira Qudsyi, Hariz Enggar Wijaya, Nur Widiasmara \\ Department of Psychology \\ Islamic University of Indonesia \\ hazhira.qudsyi@uii.ac.id
}

\begin{abstract}
This study aimed to determine whether application of Contextual Teaching and Learning can improve student's achievement and self-efficacy in Cognitive Psychology Course Period 2014-2015. The participants of this study were 230 college students. This study used quasiexperimental design with one group pre-test and post-test design. The measurement of student's achievement was done by using Cognitive Psychology Achievement Test prepared by the researchers based on the syllabus of Cognitive Psychology Course, and self-efficacy variable was measured by using SelfEfficacy Scale. Based on the test analysis, there was a significant difference on Cognitive Psychology Achievement $(p=0.000, p<0.05)$, where students achievement in post-test was bigger than that in pre-test $(M$ pre-test $=28.10$; $M$ post-test $=$ 41.00). Meanwhile, based on the test analysis, there was a significant difference on students' self-efficacy of Cognitive Psychology $(p=0.000, p<0.05)$, but students' self-efficacy in post-test was smaller than that in pre-test $(M$ pretest $=\mathbf{1 0 7 . 2 7}$; M post-test $=\mathbf{1 0 7 . 2 7}$ ).
\end{abstract}

Keywords - Contextual teaching and learning (CTL), student achievement, student self-efficacy.

\section{INTRODUCTION}

Learning is a relatively settled change that occurs both on the cognitive level and individual behavior [1]. At the behavioral level, the learning process is characterized by visible behavioral changes. In contrast, learning at mental level is generally cannot be seen directly. In the academic context, the learning process is generally measured by achievement test.

To achieve optimal learning outcomes, both learner and teacher have a significant role to follow and choose learning strategy. Hattie's meta-analysis study [2] described many factors that influence student academic achievement. The factors contributing to the academic achievement are grouped by [2] into six areas, including students, homes, schools, curriculum, teachers, and approaches to teaching. Teaching strategies, in that study, is included in factors that have a high contribution to student's achievement. That is, teachers need to consider choices of strategies and approaches in learning to optimize student academic performance.

In addition, from the personal side of students, Schunk [3] mentioned that self-efficacy is one the essential factors that also influence students in learning. The studies conducted by [4], [5], showed that there is a strong role of self-efficacy in academic achievement and student performance. Similarly, the study of $\mathrm{Li}$ [6] showed an important role of self-efficacy in predicting student academic performance.

According to the American Psychology Association Dictionary of Psychology [7], self-efficacy is defined as the ability of individuals to act effectively in order to bring the desired result, especially as perceived by people. As Bandura [8] pointed out self-efficacy is a belief in the extent to which people estimate their ability to organize and execute a necessary task or action to achieve the results. Self-efficacy depends in part on students' ability. Generally, students with high ability feel more efficacious about learning when they are compared to low-ability students; but self-efficacy is not another name for the ability. In other words, self-efficacy refers to a students' belief in their competence in a particular activity or area [9].

Furthermore, Bandura [8] explained that self-efficacy is built on four main sources of information, namely enactive mastery experiences that provide indicators of individual's abilities; vicarious experiences that change belief of individual's efficacy through the spread of competence and comparison with the results achieved by the others; verbal persuasion and similar types of social influences affect the special capabilities of people; and physiological and affective states in which some individuals assess their ability, strength, and vulnerability to dysfunction. Therefore, some efforts to improve students' self-efficacy can be done by designing the learning process that accommodates the sources of self-efficacy.

One study model that is believed to improve learning is Contextual Teaching and Learning (CTL). Johnson [10] explained that CTL is a learning system based on the 
philosophy that learners can absorb lessons or materials when they capture the meaning in academic material taken by them, and the meaning in school tasks if they could associate new information with knowledge and experiences they already had before. Learning contextually means naturally learning out the full potential of a learner. When the learners see the meaning in tasks that must be done, they can absorb the material and remember it.

Johnson [10] explained that learning process with CTL approach includes eight components. These components are making meaningful attachments, doing meaningful work, doing self-directed learning, working together, thinking critically and creatively, helping individuals to grow and develop, reaching high standards, and using authentic judgments [10]. CTL involves the learner in searching for the meaning of "context". CTL encourages them to see that humans have capacity and responsibility to influence and form a range of contexts that include family, class, community, and neighborhood. Contextual teaching and learning provides two important questions for the learner: "What are the appropriate contexts for human searching? And "What creative steps should I take to shape and give meaning to context? [10].

Several previous studies demonstrated the effectiveness of contextual learning (CTL) to student learning outcomes at various levels of education. Peni's research (2011) showed that CTL model was more effective in teaching reading comprehension than translation models. Similarly, the results of Suparman, Marhaeni, and Dantes studies (2013) indicated that CTL model was better in terms of writing ability than conventional models. The similar findings were also obtained from [11]. Laloan's study [12] showed that there was a significant difference between the learning outcomes (student's achievement) of vocational high school students in the class with CTL learning model and those of the students in the class with conventional learning strategy. Sukri [13] explained that the application of CTL could improve the student learning outcomes in solving subjects material of "addition and reduction of fractions" in elementary school. Hidayah [14] also explained in her research that application of CTL model could improve mathematics achievement of elementary students. Previous research has also shown the effectiveness of CTL learning in improving students' selfefficacy. Malanicagi's study [15] presented that there was an increase in self-efficacy among junior high school students between before and after using CTL method application.

Based on the previous studies, it can be concluded that learning with CTL model is effective in improving learning outcomes (student's achievement) and students' self-efficacy on various material objects (lessons) as well as at various levels of education. It showed that the opportunity to use CTL model in Cognitive Psychology course is very big, especially to improve students achievement and students' self-efficacy. Moreover, Cognitive Psychology course deals with how people obtain information from the world, how information is represented and transformed as knowledge, how it is stored and how knowledge is used to direct our attention and behavior. Cognitive Psychology is a course that honed sensitivity to the environment by observing people's behavior as a picture of thinking process in the brain. Based on the description, CTL model can be applied in Cognitive Psychology course among college students. Therefore, the researchers were interested in using CTL model in teaching Cognitive Psychology course that is to know whether CTL model can improve student's achievement and students' selfefficacy.

\section{RESEARCH METHOD}

The respondents in this study were students that took a Cognitive Psychology course in 2014-2015 with the total of 230 college students. This study used quasi-experimental design, with the one group pre-test-post-test design. The aim of this study was to test the effectiveness of contextual teaching and learning method on the experimental group to student's achievement and students' self-efficacy measured between pre-test and post-test.

The measurement of this study used self-report and achievement test. Self-efficacy variable was measured using Self-Efficacy Scale adapted from [16]. This scale has Cronbach Alpha's reliability coefficient 0.906 based on the tryout among 107 high school students. Self-Efficacy Scale has 33 items. The measurement of student's achievement was done by using Cognitive Psychology Achievement Test prepared by the researchers based on the syllabus of Cognitive Psychology Course.

Based on the test analysis, it was found that there was a significant difference in Cognitive Psychology Achievement $(\mathrm{p}=0.000, \mathrm{p}<0.05)$, where students achievement in post-test was bigger than pre-test $(\mathrm{M}$ pre-test $=28.10 ; \mathrm{M}$ post-test $=$ 41.00). Meanwhile, based on the test analysis, it was found that there was a significant difference in students' selfefficacy of Cognitive Psychology $(\mathrm{p}=0.000, \mathrm{p}<0.05)$, but students' self-efficacy in post-test was smaller than pre-test $(\mathrm{M}$ pretest $=107.27 ; \mathrm{M}$ posttest $=107.27)$.

\section{RESULT AND DISCUSSION}

The results can be seen in Table 1 . The results of the data analysis indicated that contextual teaching and learning (CTL model) could improve the outcomes of Cognitive Psychology learning, indicated by the increase in the student's achievement. Nevertheless, the results of the data analysis showed that CTL model could not improve the students' self-efficacy, while the empirical data showed the decrease in the students' self-efficacy.

Learning achievement or student's achievement, as a form of learning outcomes, is influenced not only by personal factors but also external factors including learning models/strategies [2]. Hattie's research [2] showed that learning strategies selected by teacher contributed significantly to student achievement. Similarly, teaching strategy (instructional strategy) also has an effect on student achievement [2]. It indicates the position of teacher as well as the chosen learning strategy are important to be concerned. 
TABLE I. RESUlts OF PAIRED SAMPLE T-TEST

\begin{tabular}{|l|l|l|c|c|c|c|}
\hline \multicolumn{2}{|c|}{ Variable } & Mean & SD & t & df & p \\
\hline $\begin{array}{l}\text { Students } \\
\text { Achievement }\end{array}$ & Pre-test & 28.10 & 17.236 & - & 235 & 0.000 \\
\cline { 2 - 5 } & Pos-ttest & 41.00 & 20.879 & 12.720 & 235 & \\
\hline $\begin{array}{l}\text { Students' Self- } \\
\text { Efficacy }\end{array}$ & Pre-test & 107.27 & 13.101 & 11.524 & 229 & 0.000 \\
\cline { 2 - 4 } & Post-test & 97.60 & 14.032 & & & \\
\hline
\end{tabular}

Learning based on contextual teaching and learning (CTL model) is included in learning model based on the philosophy that learners can absorb the lessons (material) if they grasp the meaning of material, and the meaning in schoolwork if they can associate the new information with knowledge and experience they have already possessed [10]. The learning model, according to Johnson [10], emphasizes on: making meaningful connections, doing meaningful work, self-directed learning, cooperation (teamwork), critical and creative thinking, helping individuals to grow and develop, attaining high standards, and using authentic scoring.

Through a learning model that emphasizes on the capture of the meaning by learners, the learning process can be said to emphasize on students meta-cognition. According to [2], the process has a considerable impact on student achievement. Learning by discovering meaning, elaborating, repeating, and linking to contexts that are closed with individual conditions, congenitally helps to assist memories into a long-term memory so that knowledge is not easily lost [17].

The results of this study that indicated the decrease in students' self-efficacy occurred because the level of individual expectations was different from the perceived experience. According to Bandura [8], self-efficacy is built on four main sources of information, namely enactive mastery experiences that provide indicators of individual's abilities, vicarious experiences that change beliefs of individual efficacy through the spread of competence and comparison with the results achieved by the others, verbal persuasion and similar types of social influences that affect individual's special capabilities; and physiological and affective states in which some individuals assess their ability, strength, and vulnerability to dysfunction.

Before the students experienced the direct process of learning in Cognitive Psychology Course, they still had high expectations that they could do well enough. When the individuals experienced that the subject matter was not as easy as they imagined, it made their belief to master well the lessons down, especially, when their midterms test or quiz results were perceived less than they expected at the beginning of lecturing. Self-evaluation indicating that the student felt that the lessons were difficult, has made their self-efficacy down. Another factor that can explain why CTL model was the unsuccessful experience of other students which then affects student's self-efficacy.

This study has limitations in the experimental method performed. One of this limitation is not using a comparison group. Like the other one-group pretest-posttest design studies, this study had a small internal validity because of the absence of a control group. In other words, this study provides only limited possibilities for attracting causal inference [18].

\section{CONCLUSION}

Learning based on contextual teaching and learning can improve student learning outcomes (students achievement), especially in Cognitive Psychology course. On the other hand, learning based on contextual teaching and learning is not proven to improve students' self-efficacy.

Recommendation for future research is the use of control groups as a comparison. In addition, Self-efficacy Scale used in research should be designed to focus more on the specific subject that will be measured.

\section{REFERENCES}

[1] A. Woolfolk, Educational psychology, 10th editi. Boston: Pearson Education, Inc, 2007.

[2] J. A. C. Hattie, Visible learning: A synthesis of over 800 metaanalyses relating to achievement. New York: Routledge, 2009.

[3] D. H. Schunk, Learning theories: An educational perspective, 5th edition. New Jersey: Pearson Merril Prentice Hall, 2008.

[4] R. R. Hake, “Analyzing Change/Gain Scores," 1999.

[5] M. Yusuf, "The impact of self-efficacy, achievement motivation, and selfregulated learning strategies on students' academic achievement," Procedia Soc. Behav. Sci., vol. 15, no. 2011, pp. 2623-2626, 2011.

[6] L. K. Li, "A study of the attitude, self-efficacy, effort and academic achievement of city $U$ students towards research methods and statistics," Discov. Student E-Journal, vol. 1, no. 54, pp. 154-183, 2012.

[7] G. R. VandenBos, American psychological association dictionary of psychology, 1st editio. Washington DC: American Psychological Association, 2007

[8] A. Bandura, "Self-efficacy: The exercise of control," New York, 1997.

[9] J. E. Ormrod, Human learning, 5th Edition. New Jersey: Upper Saddle River, Pearson Education, Inc., 2009.

[10] E. B. Johnson, CTL: Contextual teaching and learning. Bandung: Penerbit Kaifa, 2014.

[11] P. M. Lubis and W. Saragih, "The Effect Of Using Contextual Teaching And Learning (Ctl) Method On Students'achievement In Writing Recount Text," J. English Lang. Teach. FBS-Unimed, vol. 1, no. 2, 2012.

[12] R. A. Laloan, "Efektivitas penggunaan model pembelajaran contextual teaching learning terhadap prestasi belajar siswa pada mata pelajaran kerja bangku di SMK Muhammadiyah 1 Salam," Universitas Negeri Yogyakarta, 2013.

[13] M. Sukri, "Penerapan contextual teaching learning untuk meningkatkan hasil belajar siswa dalam menyelesaikan soal cerita penjumlahan dan pengurangan pecahan di kelas V SDN Inpres Balaroa Palu," J. Elektron. Pendidik. Mat. Tadulako, vol. 1, no. 2, pp. 159-169, 2014.

[14] N. Hidayah, "Penerapan model contextual teaching and learning untuk meningkatkan hasil belajar matematika materi bangun ruang kelas V SDN 01 Barongan Kudus," Universitas Muria Kudus.

[15] M. T. Malanicagi, "Pengembangan bahan ajar berbasis kontekstual untuk meningkatkan self-efficacy dan prestasi belajar matematika pada materi aljabar kelas 7 SMP," Universitas Negeri Yogyakarta., 2014.

[16] L. Butler, "Secondary transition experiences: Analyzing perceptions, academic self efficacy, academic adjustment and GPA for college students with learning disabilities pursuing postsecondary education," University of Maryland, 2011. 
[17] E. B. Goldstein, Cognitive psychology. Belmont: Wadsworth, 2011.

[18] E. B. Shaughnessy, J.J. Zechmeister and J.S.Zechmeister., Metodologi Penelitian Psikologi, 7th edition. Yogyakarta: Pustaka Pelajar. 